\title{
Analisis Limpasan Langsung Metode SCS Menggunakan Data Hujan TRMM Studi Kasus Sub DAS Code Hulu
}

\author{
Puji Harsanto ${ }^{a^{*}}$, Muhammad Sufyan Tsaury ${ }^{b}$ \\ ${ }^{a}$ Program Studi Teknik Sipil, Fakultas Teknik, Universitas Muhammadiyah Yogyakarta \\ ${ }^{a}$ Program Pasca Sarjana, Institut Teknologi Bandung
}

Riwayat Artikel

Diserahkan

7 Juni 2021

Direvisi

5 Agustus 2021

Diterima

28 Agustus 2021

${ }^{*}$ Penulis korespondensi puji_hr@umy.ac.id

\begin{abstract}
Abstrak
Ketersediaan data menjadi hal yang krusial dalam analisis hidrologi. Banyak permasalahan menyangkut ketersediaan data yang seringkali ditemui di lapangan, seperti minimnya data, data yang tidak kontinyu, atau sebaran stasiun yang tidak merata. Seiring berkembangnya teknologi, permasalahan tersebut dapat diselesaikan dengan memanfaatkan data pengamatan satelit yang memiliki resolusi spasial dan temporal tinggi, cakupan luas, akses cepat, dan ekonomis. Akan tetapi, data satelit perlu divalidasi dengan data pengamatan nyata di lapangan. Penelitian ini dilakukan untuk validasi data satelit TRMM terhadap data observasi berbasis darat dengan membandingkan debit limpasan dari data hujan terukur di darat atau ARR (Automatic Rainfall Recorder) dengan data hujan TRMM, lalu dikoreksi dengan debit limpasan terukur di stasiun AWLR (Automatic Water Level Recorder) Gemawang. Debit limpasan dari hujan dihitung dengan menggunakan Metode SCS. Hasil penelitian menunjukan jeda waktu rata-rata pengukuran hujan TRMM dan ARR sekitar 8,5 jam. Ditemukan perbedaan bentuk hidrograf limpasanTRMM. Pada data 18 Januari 2018, terdapat kesalahan bentuk gelombang hidrograf $(\mathrm{Ew})$ sebesar 11.843. Dari analisis indeks kesesuaian dan efisiensi, data satelit TRMM mendapat hasil koefisien korelasi rata-rata debit ARR-AWLR dan TRMM-AWLR tergolong rendah yaitu masing-masing sebesar 0,2416 dan 0,1041, sedangkan koefisien efisiensinya 1,67 yang dikategorikan sebagai data yang efisien.
\end{abstract}

Kata-kata kunci: TRMM, validasi, metode SCS, hidrologi, korelasi

\section{Abstract}

Availability of sufficient data as input data is important. Data availability tends to have several data problems, such as the lack of data availability, incomplete data, or the number of stations that are less scattered. As the development of the technology problems, those probelms can be solved by replacing ground-based observation data with satellite observations that have high spatial and temporal resolution, wide area coverage, fast access, and economics. This research was conducted to validate and correct TRMM satellite data on observation data at the AWLR Gemawang station with the SCS Method. The results of this study showed a delay in the average measurements of satellite rainfall and surface approximately 8.5 hours based on the data analysis used in this study. The results of the model error analysis can be concluded that TRMM rainfall data can be used in these needs. However, there is still an error in the TRMM data, which is on the data of January 18, 2018 which results in a hydrograph (Ew) waveform error of 11.843. From the conformity index and efficiency analysis, TRMM satellite data gets the correlation coefficient average ARR-AWLR debit of 0,2416 which is categorized as low efficiency data and TRMM-AWLR of 0,1041 which is categorized as quite low coefficient data, while the efficiency coefficient gets an average value 1,67 which is categorized as highly efficient optimization data.

Keywords: TRMM, validation, SCS method, hydrology, correlation

() 2019 Penerbit LP3M UMY. All rights reserved

\section{PENDAHULUAN}

Curah hujan adalah salah satu komponen keseimbangan air yang paling penting dalam siklus air serta memiliki variabilitas spasial dan temporal yang tinggi. Dalam perencanaan bangunan air, pengelolaan sumber daya air, dab peringatan bencana, curah ujan menjadi parameter yang menentukan keakuratan hasil kajian. Pengamatan berbasis darat menyediakan pengukuran curah hujan titik yang relatif akurat. Namun, karena heterogenitas curah hujan yang signifikan di berbagai skala spasial temporal, pengamatan pengukur hujan hanya mewakili kondisi lokal, dan dapat menghasilkan potensi kesalahan ketika diinterpolasi ke skala yang lebih besar. Oleh karena itu, data pengukur in situ biasanya tidak dapat memenuhi resolusi spasialtemporal yang tinggi. Data pengamatan curah hujan yang baik dalam segi kualias dan kuantitas (panjang data pengamatan) umumnya sulit diperoleh dalam 
perencanaan sumber daya air. Beberapa kendala seperti minimnya data, data yang tidak kontinyu, atau sebaran stasiun yang tidak merata, menyebabkan pengamatan secara insitu dianggap kurang representatif sebagai sumber data.

Seiring berkembangnya teknologi, terdapat beberapa cara untuk memperoleh informasi data hujan salah satunya dengan teknologi remot sensing atau satelit. Produk-produk curah hujan berbasis satelit memiliki keunggulan dalam hal resolusi spasial, temporal, serta cakupan areal. Salah satu produk curah hujan satelit yaitu TRMM (Tropical Rainfall Measuring Mission). TRMM adalah satelit yang dibangun dan dikembangkan bersama oleh USA NASA dan JAXA (Badan Aerospasial Jepang) (Collischonn, Collischonn, \& Tucci, 2008).

Untuk mengetahui apakah data satelit cukup mewakili kondisi nyata di lapangan, perlu adanya validasi data. Penelitian ini akan mengkaji validitas data pengukuran curah hujan berbasis darat dengan data satelit. Adjei dkk (2012) dan Cao dkk (2018) menguji validitas dan mengevaluasi data curah hujan satelit dengan data lapangan dalam skala waktu bulanan dan tahunan. Penelitian tersebut dilakukan di lokasi DAS yang berbeda yaitu Black Volta di Ghana dan Yangtze River Delta di China. Hasil penelitian Adjei dkk (2012) menunjukkan bahwa nilai koefisien korelasi rata-rata data curah hujan bulanan memiliki hasil yang baik yaitu 0,94 dibanding dengan data curah hujan tahunan. Cao dkk (2018) mengevaluasi data hujan satelit dengan 56 stasiun hujan. Penelitian Cao dkk (2018) menghasilkan koefisien korelasi sebesar 0,88 untuk skala tahunan, 0,96 untuk skala bulanan pada nilai tertinggi, dan 0,79 pada nilai terendah. Ali dkk (2017) mengamaati evaluasi untuk skala musiman dan menyatakan bahwa hasil evaluasi pada skala musiman kurang baik. Begitu juga menurut Wang dkk (2017), hasil yang di dapat kurang baik tetapi ada konsistensi yang sedikit lebih baik antara produk satelit dan pengukuran yaitu pada musim gugur. Kajian studi terdahulu menunjukkan bahwa pola hujan yang berbedabeda mempengaruhi kesesuaian data curah hujan lapangan dengan produk data curah hujan satelit. Pada wilayah dengan pola hujan equatorial, data satelit menunjukan overestimate yang cukup besar pada musim hujan terutama pada bulan puncak hujan sedangkan pada wilayah lokal, data satelit cenderung underestimate (Mamenun, dkk., 2014). Berdasarkan penelitianpenelitian sebelumnya, perlu dilakukan evaluasi khusus mengenai korelasi antara hujan satelit dan hujan berbasis darat pada kondisi iklim dan pola hujan tertentu.

Penelitian bertujuan untuk validasi data satelit TRMM terhadap data observasi berbasis darat dengan membandingkan debit limpasan dari data hujan terukur di darat atau ARR (Automatic Rainfall Recorder) dengan data hujan TRMM, lalu dikoreksi dengan debit limpasan terukur di stasiun AWLR (Automatic Water Level Recorder) Gemawang pada Sub DAS Code hulu.

\section{METODE PENELITIAN}

\subsection{Lokasi}

Lokasi Daerah Aliran Sungai (DAS) yang digunakan dalam penelitian ini adalah Sub DAS Code hulu yang terletak di Provinsi Daerah Istimewa Yogyakarta. Karakteristik sub DAS Code hulu ditampilkan pada Tabel 1.

Tabel 1. Karakteristik sub DAS Code hulu

\begin{tabular}{lll}
\hline No. & Karakteristik & Nilai \\
\hline 1 & Luas sub DAS Code & $24,76 \mathrm{~km}^{2}$ \\
2 & Panjang sungai utama & $27,44 \mathrm{~km}$ \\
3 & Kemiringan sub DAS & 0,094 \\
\hline
\end{tabular}

\subsection{Data Hujan dan Debit Limpasan}

Data hujan yang digunakan adalah curah hujan hasil pengukuran penakar hujan di dua stasiun pengukuran hujan dengan interval 5 menit dan data hujan harian produk satelit GPM (Global Precipitation Measurement) Final Precipitation dengan resolusi spasial $0.1^{\circ} \times 0.1^{\circ}$. Lokasi penelitian dapat dilihat pada Gambar 1, sedangkan sebaran data hujan di sekitar lokasi penelitian ditunjukkan pada Gambar 2. Analisa hujan rata-rata DAS dilakukan dengan metode poligon Thiessen yang proses pembuatannya menggunakan Analysis Tools Thiessen Polygon pada software ArcMap 10.2.1. Luas daerah pengaruh stasiun berdasarkan metode Thiessen ditunjukkan pada Tabel 2. Data debit limpasan diambil dari pengukuran muka air AWLR Gemawang yang

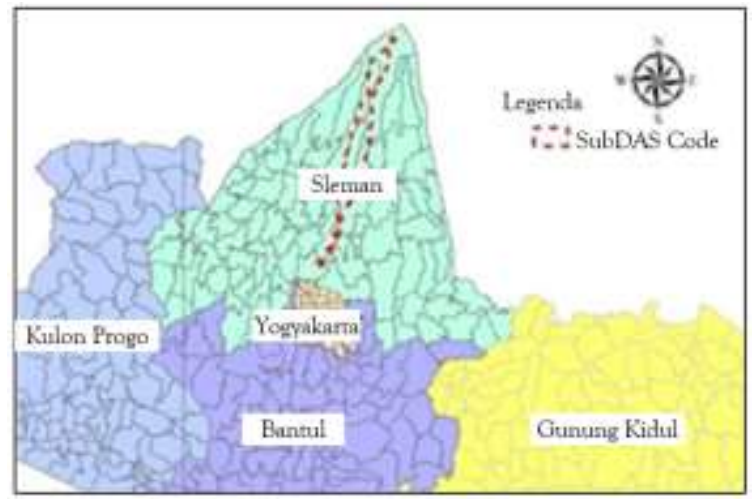

Gambar 1 Lokasi Penelitian

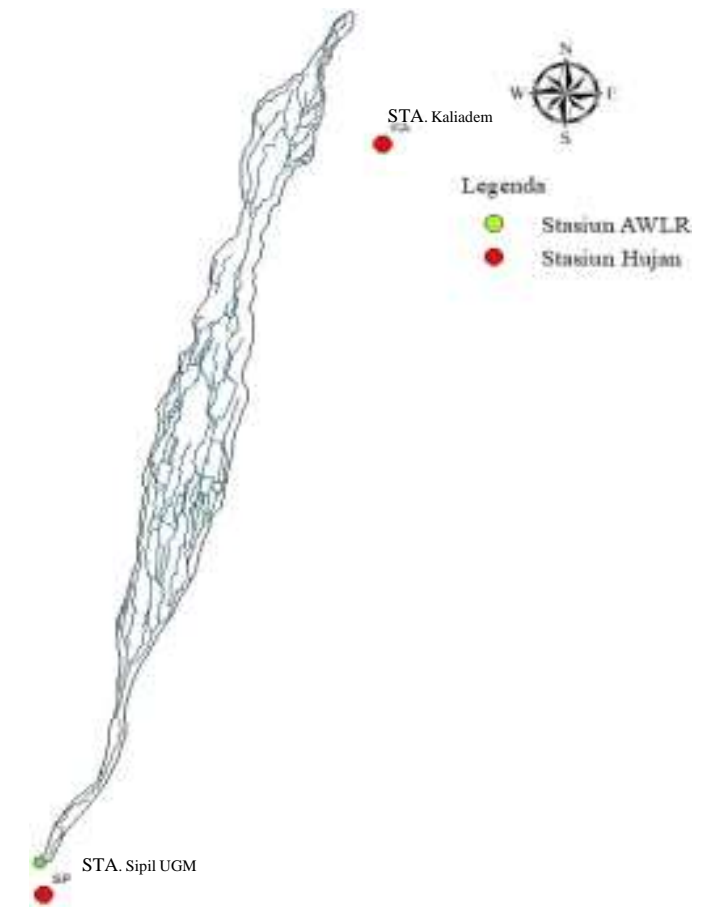

Gambar 2 Peta sebaran stasiun hujan sub DAS Code hulu 


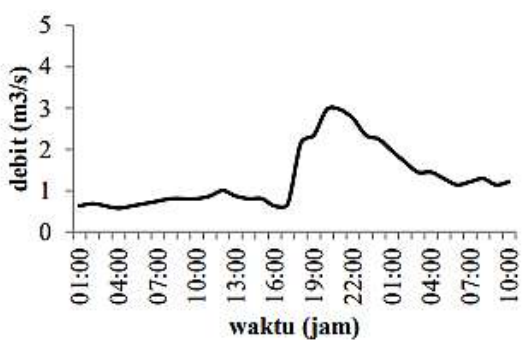

(a)

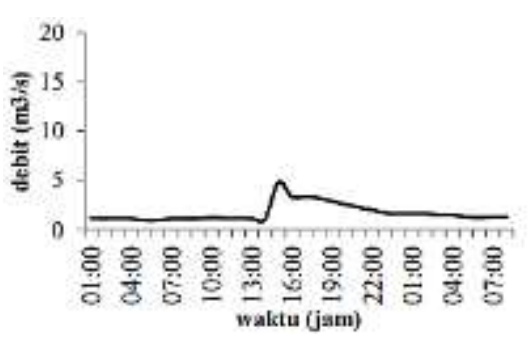

(c)

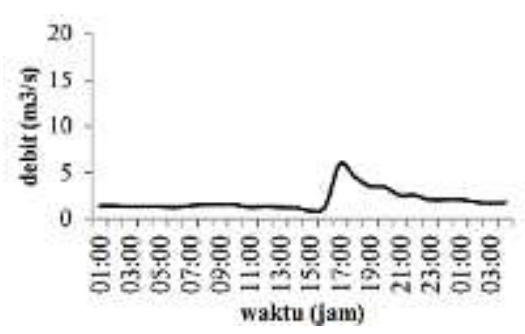

(e)

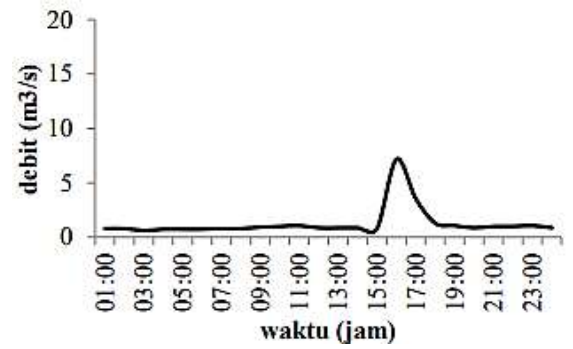

(b)

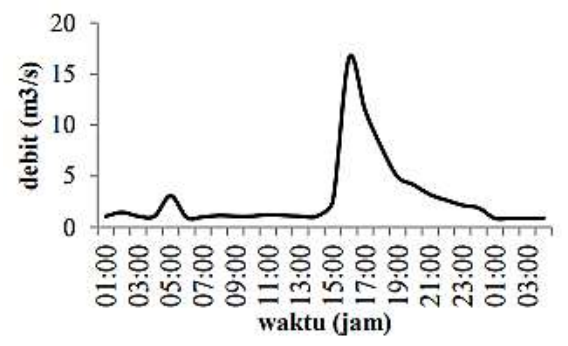

(d)

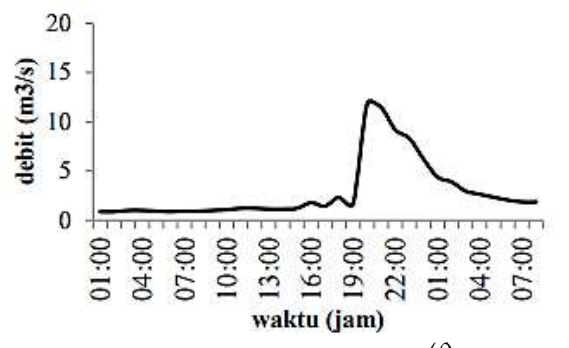

(f)

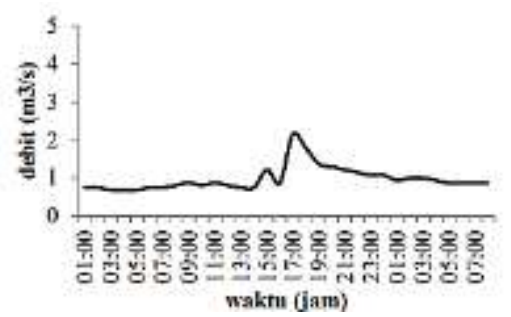

(g)

Gambar 3 Data debit sungai di AWLR Gemawang pada (a) 16-17 Januari 2018; (b) 18 Januari 2018; (c) 22 - 23 Januari 2018;

(d) 2-3 Februari 2018; (e) 4-5 Februari 2018; (f) 7-8 Februari 2018; (g) 26 - 27 November 2017

dialihragamkan menjadi data debit pada 9 catatan kejadian (Gambar 3(a) sampai dengan Gambar 3(g)).

Tabel 2. Luas daerah pengaruh stasiun hujan

\begin{tabular}{|c|c|c|c|c|}
\hline \multirow{2}{*}{ No } & \multirow{2}{*}{ Stasiun } & \multicolumn{2}{|l|}{ Koordinat } & \multirow{2}{*}{$\begin{array}{l}\text { Luas Area } \\
-\left(\mathrm{km}^{2}\right)\end{array}$} \\
\hline & & Longitude & Latitude & \\
\hline 1 & $\begin{array}{l}\text { ARR Sipil } \\
\text { UGM }\end{array}$ & 110.3723675 & -7.764741328 & 7.368 \\
\hline \multirow[t]{2}{*}{2} & ARR Kaliadem & 110.4475194 & -7.583641424 & 17.387 \\
\hline & & Jumlah & & 24.755 \\
\hline
\end{tabular}

\subsection{Tata Guna Lahan DAS}

Peta tata guna lahan wilayah Sub DAS Code hulu diunduh dari website Badan Informasi Geospasial (2017). Peta ini dibutuhkan untuk menentukan koefisien penutup lahan dalam perhitungan debit. Luas penutup lahan pada sub DAS Code ditunjukan pada Tabel 3.

Tabel 3. Luas penutup lahan pada sub DAS Code

\begin{tabular}{lll}
\hline No & Lahan Penutup & Luas Area $\left(\mathrm{km}^{2}\right)$ \\
\hline 1 & Hutan & 3.794 \\
2 & Padang Rumput & 0.056 \\
3 & Kebun / Perkebunan & 1.706
\end{tabular}

\begin{tabular}{lll}
4 & Gedung / Bangunan / Pemukiman & 4.812 \\
5 & Sawah & 11.549 \\
6 & Tegalan / Ladang & 1.926 \\
7 & Semak Belukar & 0.913 \\
\hline Jumlah & 24.755 \\
\hline
\end{tabular}

\subsection{Analisis Hujan Efektif}

Salah satu metode yang mentransformasikan volume curah hujan ke dalam volume limpasan langsung yaitu metode SCS-CN. Metode ini didasarkan pada parameter retensi (S), initial abstraction (Ia), dan hujan harian. Penentuan nilai CN dikelompokkan dalam satu jenis tanah yaitu kelompok tanah B dalam Hydrologic Soil Groups, maka luasan dan nilai CN di DAS Code hulu identik dengan tataguna lahan saja. Nilai Curve Number (CN) ditunjukan pada Tabel 4. Parameter retensi (S) adalah variabel yang berhubungan langsung dengan jenis tanah, tataguna lahan, dan kelembaban tanah (Harsanto, dkk., 2015). Persamaan untuk menghitung nilai parameter retensi adalah sebagaimana ditunjukkan pada Persamaan (1).

$$
S=25,4\left(\frac{1000}{\mathrm{CN}}-10\right)
$$


dengan $S$ adalah parameter retensi, dan $\mathrm{CN}$ adalah curve number. Initial abstraction (Ia) adalah fungsi penggunaan tanah, perlakuan dan kondisi, serta kandungan air tanah sebelumnya. Parameter ini mewakili nilai intersepsi, evaporasi, dan penahan air yang mempengaruhi kemungkinan terjadinya limpasan langsung. Persamaan untuk menentukan nilai Ia adalah sebagai berikut:

$$
I a=\lambda \times S
$$

dengan $\lambda$ adalah rasio abstraksi, berkisaran 0 sampai 0,3 .

Tabel 4. Nilai curve number (CN)

\begin{tabular}{lllll}
\hline No & Lahan Penutup & $\begin{array}{l}\text { Luas Area } \\
\left(\mathrm{km}^{2}\right)\end{array}$ & $\begin{array}{l}\text { Persentase } \\
(\%)\end{array}$ & $\mathrm{CN}$ \\
\hline 1 & Hutan & 3.794 & 15,325 & 55 \\
2 & Padang Rumput & 0.056 & 0,227 & 69 \\
3 & Kebun / Perkebunan & 1.706 & 6,891 & 65 \\
4 & Gedung / Bangunan / & 4.812 & 19,439 & 71 \\
5 & Pemukiman & 11.549 & 46,651 & 75 \\
6 & Sawah & 1.926 & 3,688 & 56 \\
7 & Tegalan / Ladang & 0.913 & 7,778 & 69 \\
\hline
\end{tabular}

\subsection{Rating Curve}

Data muka air yang didapat dari Stasiun AWLR Gemawang yang dialihragamkan menjadi data debit aliran dengan persamaan berikut.

$$
Q(t)=10,861\left(x^{1,7672}\right)
$$

dengan $Q$ adalah debit aliran sungai $\left(\mathrm{m}^{3} / \mathrm{s}\right)$ dan $x$ adalah muka air sungai $(\mathrm{m})$. Persamaan di atas diperoleh dari pengukuran di lapangan dengan membandingkan debit terukur di ruas sungai dengan bacaan tinggi muka air di stasiun pengamatan.

\subsection{Aliran Dasar}

Menurut Furey dan Gupta (2001), untuk memperkirakan besarnya kontribusi aliran dasar pada DAS Code hulu, maka perlu dilakukan permisahan hidrograf debit aliran dasar dari hidrograf debit aliran sungai. Proses pemisahan hidrograf debit aliran dasar (baseflow) dari hidrograf aliran sungai yaitu dengan mengasumsikan debit aliran dasar memiliki nilai yang sama.

\subsection{Koefisien Korelasi dan Efisiensi}

Pada penelitian ini koefisien korelasi $\left(\mathrm{R}^{2}\right)$ digunakan untuk menunjukan besarnya keterkaitan antara data observasi dan satelit, sedangkan koefisien efisiensi digunakan untuk menguji efisiensi model hidrograf terhadap debit observasi dan satelit. Menurut Henda dkk (2015), koefisien efisiensi dapat dihitung dengan metode berikut.

$$
C E=\frac{\sum_{i=1}^{n}\left(Q_{o}(i)-Q_{c}(i)\right)^{2}}{\sum_{i=1}^{n}\left(Q_{o}(i)-Q_{o} \text { rata-rata }(i)\right)^{2}}
$$

dengan Qo $(i)$ adalah debit terukur $\left(\mathrm{m}^{3} / \mathrm{s}\right)$ dan $\left.\mathrm{Qc}_{c} \mathrm{i}\right)$ adalah debit terhitung $\left(\mathrm{m}^{3} / \mathrm{s}\right)$.

Ratner (2009) menginterpretasikan hubungan dua variabel berdasarkan nilai koefisien korelasi yang ditunjukkkan pada Tabel 5. Jika, dilihat dari koefisien efisiensi, kecocokan suatu model terhadap data dapat dikateorikan ke dalam beberapa kriteria sebagaimana dicantumkan dalam Tabel 6 (Ladson, 2008).

Tabel 5. Kategori nilai koefisien korelasi (Ratner, 2009)

\begin{tabular}{ll}
\hline Koefisien Korelasi & Kategori \\
\hline 0 & Tidak berkaitan \\
$0-0,3$ & Korelasi rendah \\
$0,3-0,7$ & Korelasi sedang \\
$0,7-1,0$ & Korelasi kuat \\
\hline
\end{tabular}

Tabel 6. Kategori nilai koefisien efisiensi (Ladson, 2008)

\begin{tabular}{lll}
\hline $\begin{array}{l}\text { Koefisien Efisiensi } \\
\text { (Kalibrasi) }\end{array}$ & $\begin{array}{l}\text { Koefisien Efisiensi } \\
\text { (Validasi) }\end{array}$ & Kategori \\
\hline$<0,6$ & $<0,3$ & Lemah \\
$0,6-0,7$ & $0,3-0,6$ & Cukup Baik \\
$0,7-0,8$ & $0,6-0,8$ & Memuaskan \\
$0,8-0,93$ & $0,8-0,93$ & Baik \\
$>0,93$ & $>0,93$ & Sangat Baik \\
\hline
\end{tabular}

\subsection{Evaluasi Ketelitian Model}

Menurut Aziz dan Tanaka (2011), untuk mengkaji ketelitian suatu model ada beberapa indikator penilaian antara lain kesalahan bentuk gelombang, kesalahan volume, dan kesalahan debit puncak yang di kembangkan oleh Japan Institute of Construction Engineering (JICE).

Kesalahan bentuk gelombang, Ew :

$$
E w=\frac{1}{n} \sum_{i=1}^{n}\left(\frac{Q_{o}(i)-Q_{c}(i)}{Q_{o}(i)}\right)^{2}
$$

Kesalahan volume, Ev :

$$
E v=\frac{\sum_{i=1}^{n} Q_{o}(i)-\sum_{i=1}^{n} Q_{c}(i)}{\sum_{i=1}^{n} Q_{o}(i)}
$$

Kesalahan debit puncak, Ep :

$$
E p=\frac{Q_{o p}-Q_{c p}}{Q_{o p}}
$$

dengan $Q_{o}(i)$ adalah debit terukur $\left(\mathrm{m}^{3} / \mathrm{s}\right)$, dan $Q_{c}(i)$ adalah debit terhitung $\left(\mathrm{m}^{3} / \mathrm{s}\right)$.

\section{HASIL DAN PEMBAHASAN}

\subsection{Analisis Curah Hujan TRMM}

Hasil analisis hujan rata-rata ditampilkan pada Gambar 4. Pada Gambar 4, terlihat bahwa hujan TRMM merekam kejadian hujan lebih awal dari hujan $A R R$ dengan jeda waktu rerata 8,5 jam.

\subsection{Analisis Debit Limpasan}

Analisis ini dilakukan untuk menghitung limpasan langsung yang terjadi pada suatu DAS tertentu. Hasil dari analisis ini diharapkan mampu mendekati dengan debit yang terjadi sebenarnya. Hidrograf satuan sintetis perlu dikoreksi agar tinggi limpasan langsung yang dihasilkan sama dengan $1 \mathrm{~mm}$ sehingga volume limpasan yang dihasilkan akan sama dengan volume hujan. Hasil analisis limpasan langsung ditampilkan pada Gambar 5. 

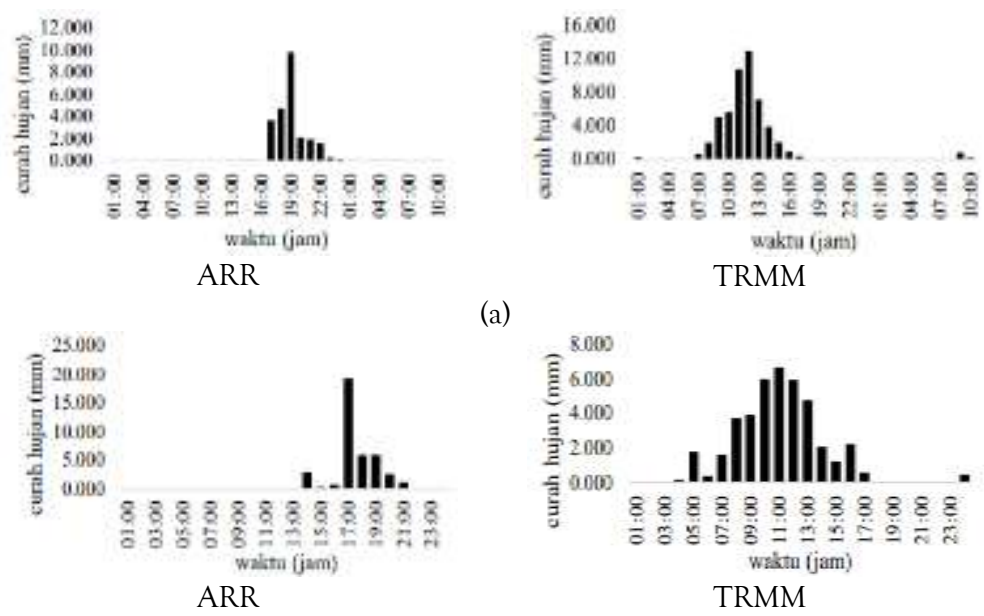

(a)

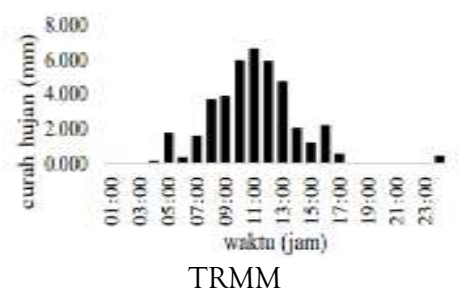

(b)
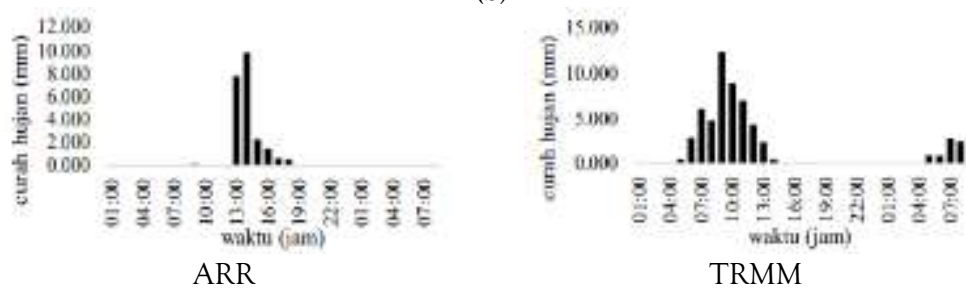

(c)
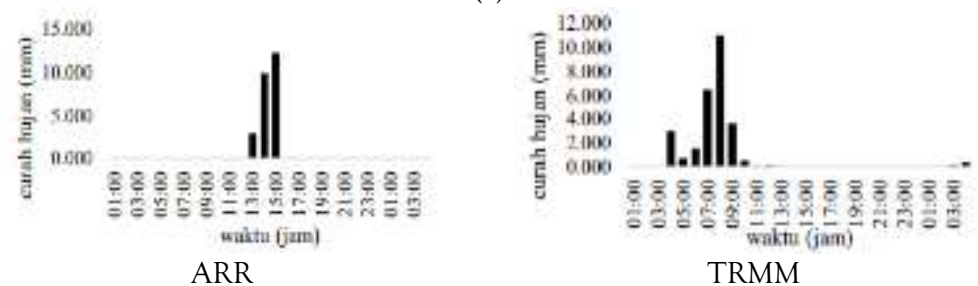

(d)
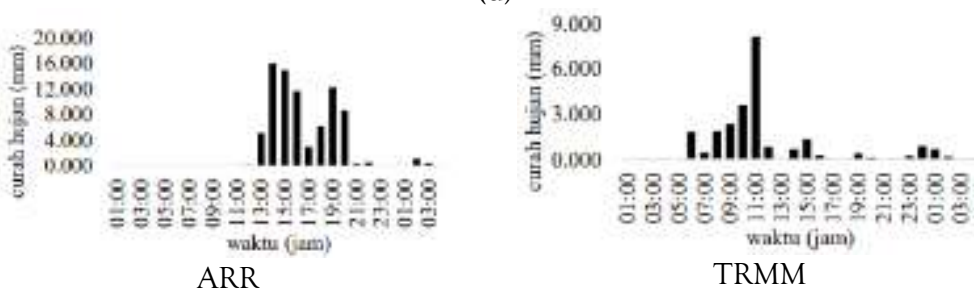

(e)
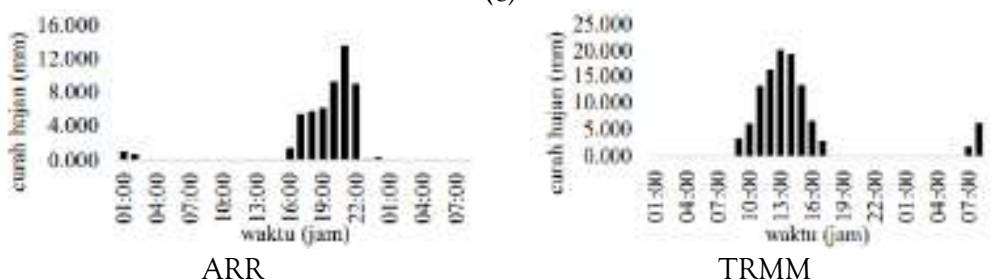

(f)
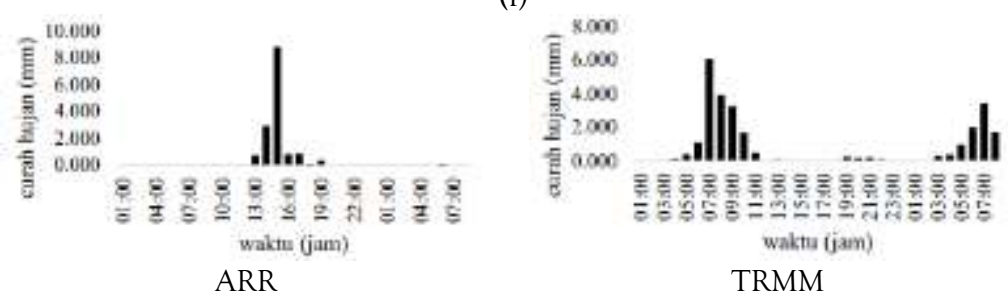

(g)

Gambar 4. Curah hujan rerata ARR dan TRMM pada (a) 16-17 Januari 2018, (b) 18 Januari 2018, (c) 22-23 Januari, (d) 2-3 Februari 2018, (e) 4-5 Februari 2018, (f) 7-8 Februari 2018, dan (g) 26-27 November 2017 

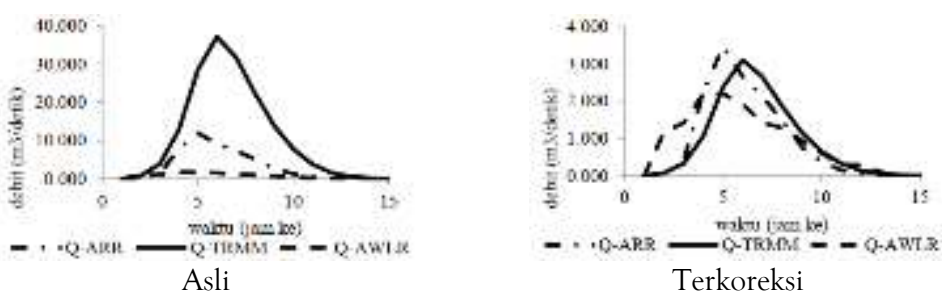

(a)
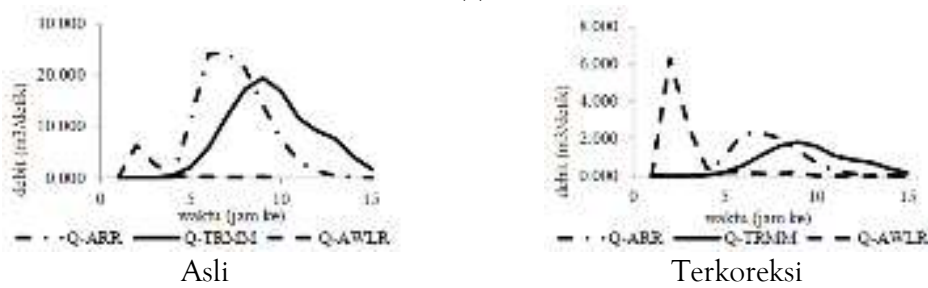

(b)
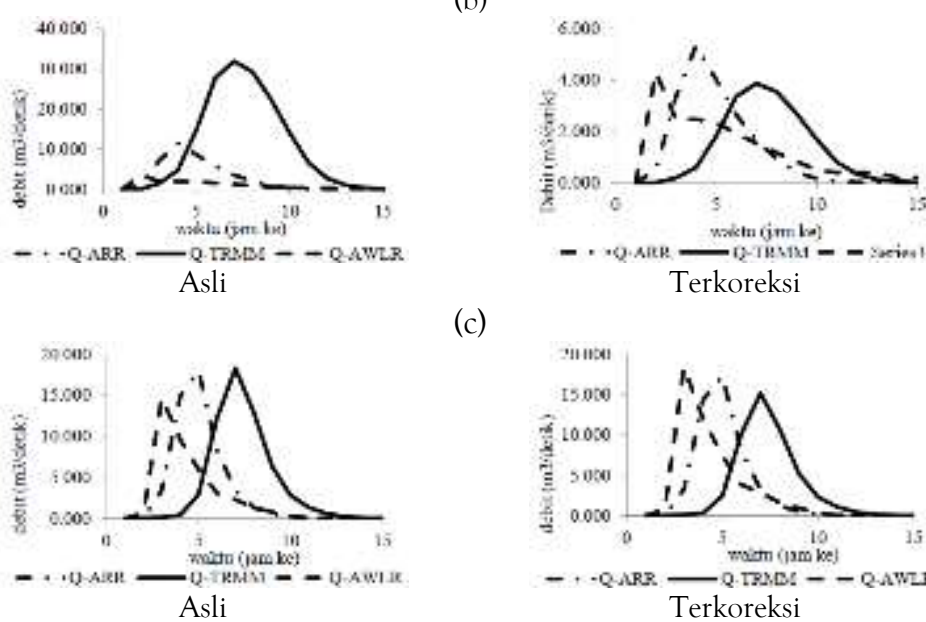

(c)

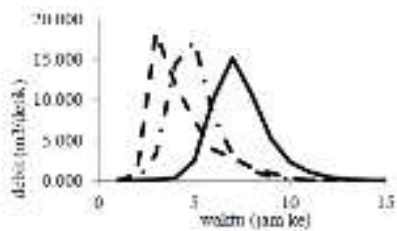

- - QURR - QTRMDS - - QAWLR Terkoreksi

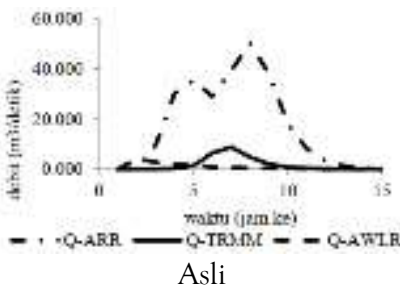

(d)
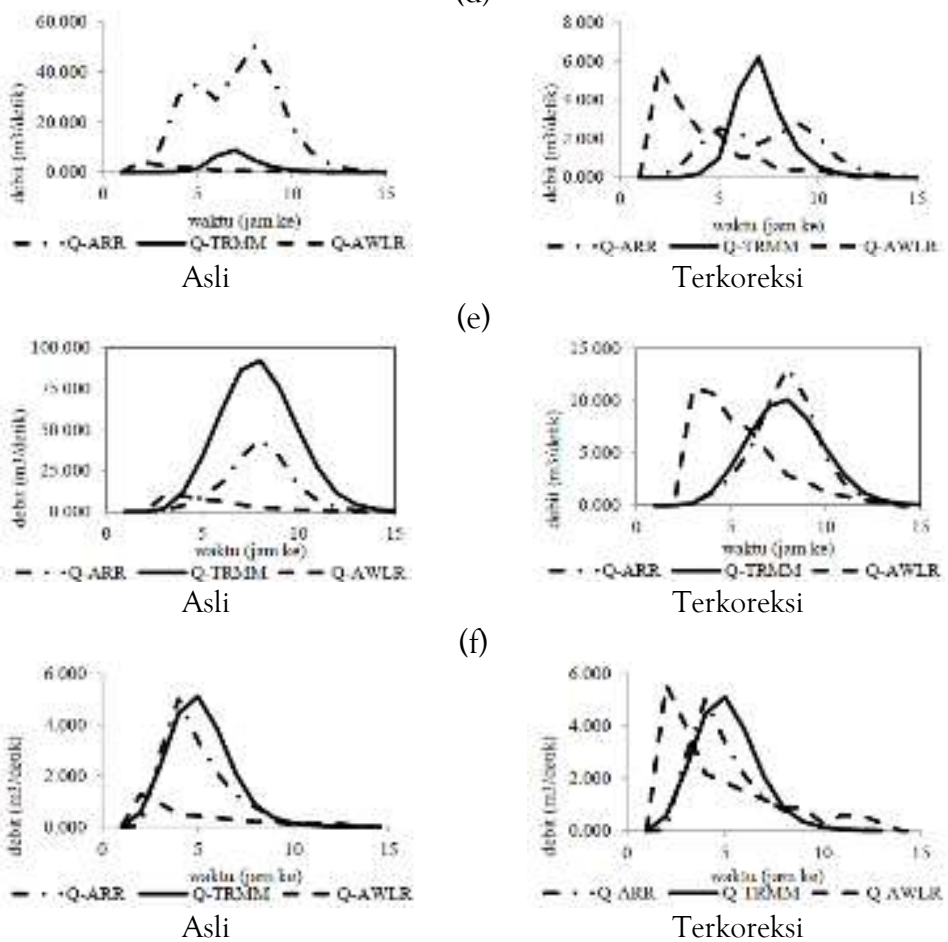

(g)

Gambar 4. Curah hujan rerata ARR dan TRMM pada (a) 16-17 Januari 2018, (b) 18 Januari 2018, (c) 22-23 Januari, (d) 2-3 Februari 2018, (e) 4-5 Februari 2018, (f) 7-8 Februari 2018, dan (g) 26-27 November 2017 
Tabel 6. Nilai debit puncak dan volume hidrograf

\begin{tabular}{lllllll}
\hline Tanggal & Qp (ARR) & $\begin{array}{l}\text { Qp } \\
\text { (TRMM) }\end{array}$ & $\begin{array}{l}\text { Qp } \\
\text { AWLR })\end{array}$ & Volume ARR $\left(\mathrm{m}^{3}\right)$ & $\begin{array}{l}\text { Volume TRMM } \\
\left(\mathrm{m}^{3}\right)\end{array}$ & Volume AWLR $\left(\mathrm{m}^{3}\right)$ \\
\hline 20-21 Jan 17 & 3,33 & 2,58 & 2,29 & 40275,35 & 40275,35 & 40275,35 \\
16-17 Mar 17 & 2,21 & 2,02 & 3,03 & 23185,49 & 23185,49 & 23185,49 \\
26-27 Nov 17 & 1,46 & 1,20 & 1,31 & 16732,71 & 16736,10 & 16737,16 \\
16-17 Jan 18 & 3,47 & 3,11 & 2,19 & 49623,34 & 49512,46 & 49689,03 \\
18 Jan 18 & 2,30 & 1,82 & 6,28 & 36823,18 & 36823,18 & 36823,18 \\
22-23 Jan 18 & 5,35 & 3,88 & 4,31 & 68815,45 & 68814,44 & 68815,45 \\
02-03 Feb 18 & 17,25 & 15,15 & 18,37 & 173659,61 & 173650,55 & 173655,86 \\
04-05 Feb 18 & 2,78 & 6,20 & 5,73 & 63232,83 & 63232,83 & 63232,83 \\
07-08 Feb 18 & 13,18 & 10,12 & 11,22 & 181251,54 & 181251,54 & 181251,54 \\
\hline
\end{tabular}

Tabel 7. Hasil analisis kesalahan model hidrograf

\begin{tabular}{lllll}
\hline \multirow{2}{*}{ Tanggal } & \multicolumn{2}{c}{ Wave Shape Error (Ew) } & \multicolumn{2}{c}{ Peak Discharge Error (Ep) } \\
\cline { 2 - 5 } 20-21 Jan 17 & ARR & 1,215 & ARR & TRMM \\
16-17 Mar 17 & 1,058 & 2,376 & 0,452 & 0,123 \\
26-27 Nov 17 & 0,400 & 0,838 & 0,255 & 0,333 \\
16-17 Jan 18 & 0,393 & 0,888 & 0,116 & 0,086 \\
18 Jan 18 & 0,219 & 11,843 & 0,582 & 0,416 \\
22-23 Jan 18 & 29,851 & 0,821 & 0,633 & 0,710 \\
02-03 Feb 18 & 0,488 & 6,711 & 0,241 & 0,101 \\
04-05 Feb 18 & 0,316 & 5,833 & 0,061 & 0,175 \\
07-08 Feb 18 & 7,451 & 0,888 & 0,515 & 0,082 \\
\hline
\end{tabular}

\subsection{Hasil Evaluasi Ketelitian Model}

Analisis Ew pada model 18 Januari 2018 mendapat hasil sebesar 29.851 untuk hidrograf debit ARR dan 11.843 untuk hidrograf debit TRMM. Nilai kesalahan tersebut mengindikasikan bahwa model masih kurang akurat, untuk itu perlu dilakukan peningkatan akurasi. Semakin mendekati nilai 0 (nol) maka hasil pemodelan semakin baik. Hasil evaluasi ketelitian model ditampilkan pada Tabel 6 dan Tabel 7.

\subsection{Koefisien Korelasi Debit Limpasan ARR dan TRMM}

Koefisien korelasi antara debit limpasan yang dihasilkan dari ARR dan TRMM dapat dilihat pada Tabel 8. Berdasarkan nilai coefficient of determination $\left(R^{2}\right)$ antara debit dari ARR dan TRMM mendapatkan hasil kesesuaian yang tidak konsisten. Nilai korelasi rata-rata debit ARRAWLR sebesar 0,2416 yang dikategorikan sebagai data keofisien rendah dan TRMM-AWLR sebesar 0,1041 yang dikategorikan sebagai data koefisien cukup rendah.

Tabel 8. Hasil analisis korelasi

\begin{tabular}{lll}
\hline Tanggal & ARR-AWLR $\left(R^{2}\right)$ & TRMM-AWLR $\left(R^{2}\right)$ \\
\hline 20, 21 Jan 17 & 0,1119 & 0,0256 \\
16, 17 Mar 17 & 0,3088 & 0,0056 \\
26, 27 Nov 17 & 0,1481 & 0,1381 \\
16, 17 Jan 18 & 0,7800 & 0,6161 \\
18 Jan 18 & 0,0214 & 0,0523 \\
22, 23 Jan 18 & 0,3983 & 0,0314 \\
02, 03 Feb 18 & 0,3561 & 0,0018 \\
04, 05 Feb 18 & 0,0155 & 0,00003 \\
07, 08 Feb 18 & 0,0341 & 0,066 \\
\hline
\end{tabular}

Hasil analisis keofisien efisiensi menunjukan bahwa hampir seluruh data memiliki nilai lebih dari 0,75 (sangat efisien) yang airtinya bahwa data memiliki kecocokan secara keseluruhan. Hasil analisis koefisien efisiensi dapat dilihat pada Tabel 9.
Tabel 9. Hasil analisis koefisien efiensi

\begin{tabular}{lll}
\hline Tanggal & CE (ARR) & CE (TRMM) \\
\hline 20, 21 Jan 17 & 2,16 & 2,14 \\
16, 17 Mar 17 & 0,66 & 1,61 \\
26, 27 Nov 17 & 1,57 & 1,45 \\
16, 17 Jan 18 & 0,47 & 0,63 \\
18 Jan 18 & 1,48 & 1,38 \\
22, 23 Jan 18 & 1,08 & 2,24 \\
02, 03 Feb 18 & 0,83 & 1,89 \\
04, 05 Feb 18 & 1,32 & 2,29 \\
07, 08 Feb 18 & 1,73 & 1,39 \\
\hline
\end{tabular}

\section{KESIMPULAN}

Dari hasil penelitian mengenai Analisis Hidrologi Metode SCS Menggunakan Data Hujan TRMM pada sub DAS Code dapat diketahui bahwa data curah hujan TRMM dapat digunakan dalam kebutuhan perencanaan untuk mengatasi keterbatasan data curah hujan terukur di stasiun pengamatan. Jeda waktu (delay) rata-rata pengukuran curah hujan satelit dan darat kurang lebih 8.5 jam. Nilai kesalahan yang diperoleh dari evaluasi bentuk gelombang mengindikasikan bahwa model masih kurang akurat dan perlu dilakukan peningkatan akurasi. Dari analisis indeks kesesuaian dan efisiensi, dapat disimpulkan sebagai data yang lebih sesuai dengan data pengukuran AWLR. Pada penilitiaan ini koefisien korelasi rata-rata debit ARR-AWLR sebesar 0,2416 yang dikategorikan sebagai data keofisien rendah dan TRMMAWLR sebesar 0,1041 yang dikategorikan sebagai data koefisien cukup rendah, sedangkan untuk koefisien efisiensi mendapat nilai rata-rata 1,67 yang dikategorikan sebagai data optimasi yang sangat efisien. Perbedaan tinggi curah hujan antara data satelit dan data observasi bersifat dinamis. Hasil estimasi hujan dari satelit dapat berubah akibat adanya faktor yang mempengaruhi meteorologi seperti angin dan perbedaan tekanan sebelum jatuh menjadi hujan ke permukaan. 


\section{Daftar Pustaka}

Adjei, K., Ren, L., Appiah-Adjei, E., Kankam-Yeboah, K., \& Agyapong, A. (2012). Validation of TRMM Data in the Black Volta Basin of Ghana. Journal of Hydrological Engineering, 17(5), 647-654.

Ali, A., Xiao, C., Anjum, M., Adnan, M., Nawaz, Z., Ijaz, M., . . . Farid, H. (2017). Evaluation and Comparison of TRMM Multi-Satellite Precipitation Products With Reference to Rain Gauge Observations in Hunza River Basin, Karakoram Range, Nothern Pakistan. Sustainability, 9(11), 1954-1973.

Aziz, A., \& Tanaka, S. (2011). Regional Parameterization and Applicability of Integrated Flood Analysis System (IFAS) for Flood Forecasting of Upper-Middle Indus River. Pakistan Journal of Meteorology, 8(15), 21-38.

Badan Informasi Geospasial. (2017). Ina-GeoPortal. Retrieved from https://tanahair.indonesia.go.id/portal-web

Cao, Y., Zhang, W., \& Wang, W. (2018). Evaluation of TRMM 3B43 data over the Yangtze River Delta of China. Scientific Reports, 8(1), 5290-5302.

Collischonn, B., Collischonn, W., \& Tucci, C. E. (2008). Daily hydrological modeling in the Amazon basin using TRMM rainfall estimates. Journal of Hydrology, 360(14), 207-216.
Furey, P., \& Gupta, V. (2001). A physically based filter for separating base flow from streamflow time series. Water Resources Research, 37(11), 2709-2722.

Harsanto, P., Ikhsan, J., \& Alamyah, B. (2015). Model Hidrograf Banjir NRCS CN Modifikasi. Simposium Nasional Teknologi Terapan (SNTT)3. Surakarta: Universitas Muhammadiyah Surakarta.

Hendra, Y., Fauzi, M., \& Sutikno, S. (2015). Pemanfaatan Dara ARR (Automatic Rainfall Recorder) Untuk Peningkatan Efektifitas Model Hujan Satelit (Studi Kasus DAS Indragiri). Jurnal Online Mahasiswa (JOM) Bidang Teknik dan Sains, 2(2), 1-14.

Ladson, A. (2008). HIdrology, An Australian Introducction. Docklands: Oxford University Press Australia.

Ratner, B. (2009). The correlation coefficient: Its values range between $+1 /-1$, or do they? Journal of Targeting, Measurement and Analysis for Marketing, 17, 139-142.

Wang, G., Zhang, P., Liang, L., \& Zhang, S. (2017). Evaluation of precipitation from CMORPH GPCP-2, TRMM 3B43, GPCC, and ITPCAS with ground-based measurements in the Qinling-Daba Mountains, China. Plos One, 12(10), e0185147. 